\title{
Phenomenology of vernacular environments: Wancho settlements in Arunachal Pradesh, in the north east of India
}

Fenomenología de los entornos vernáculos: Los

asentamientos wancho de Arunachal Pradesh, en el

nordeste de la India

Fenomenologia dos ambientes vernaculares: Povoações
de wancho em Arunachal Pradesh, no nordeste da
Índia

Keywords $\mid$ Palabras clave $\mid$ Pallaviras chave

Place identity, Indigenous culture, Cultural identity, Indigenous institutions, Tribal identity

Identidad del lugar, Cultura autóctona, Identidad cultural, Instituciones autóctonas, Identidad tribal

Identidade local, Cultura indígena, Identidade cultural, Instituições indígenas, Identidade tribal

\begin{abstract}
Resumen | Resumo
This paper explores the Wancho communities in the Longding District of Arunachal Pradesh, located in the north-east of India, analysing their architecture in its traditional cultural and geographical context. Through a phenomenological study of the landscape and architecture of the Wancho, it reveals how these communities create forms and inscribe their particular patterns upon the landscape, resulting in a unique built expression. Phenomenology emphasizes lived experience and enquires into the related concepts of space and place, understanding how physical phenomena are inscribed with meanings. Accordingly, the Wancho settlements in Arunachal Pradesh have been seen through the lens of lived-experiences that provide them with meanings. In Wancho settlements the emotional and subjective attachment of the community to their place is strong, and is reflected through the material reality of the village and its environment. Seen as a whole, the settlements integrate climatic and other natural environmental factors, as well as the cultural institutions, values and practices of these people, which are also reflected through the craft and local skills of the community. The traditional Wancho settlements are "read" here by considering their landscape and townscape as "texts".
\end{abstract}

Este artículo estudia las comunidades wancho del distrito de Longding, en el estado de Arunachal Pradesh, al nordeste de la India, y analiza su arquitectura en su contexto cultural y geográfico tradicional. A través de un estudio fenomenológico del paisaje y la arquitectura de los wancho, se muestra cómo estas comunidades crearon formas y dejaron su huella particular en el paisaje, lo que ha producido una manifestación construida única. La fenomenología subraya la experiencia vivida e indaga en los conceptos afines de espacio y lugar, entendiendo cómo adquieren significado los 
fenómenos físicos. En consecuencia, los asentamientos wancho de Arunachal Pradesh se han observado a través de las experiencias vividas que les proporcionan sentido. En los asentamientos wancho hay un fuerte apego emocional y subjetivo de la comunidad por su espacio, que se refleja en la realidad material del pueblo y su entorno. Vistos en conjunto, los asentamientos tienen en cuenta el clima y otros factores medioambientales, así como las instituciones, los valores y las prácticas culturales de estos pueblos, que también se reflejan en la artesanía y las habilidades locales de la comunidad. Los asentamientos wancho tradicionales se "leen" aquí considerando su paisaje natural y urbano como "textos".

Este artigo explora as comunidades wancho no distrito de Longding de Arunachal Pradesh, localizado no nordeste da Índia, analisando a sua arquitectura no seu contexto cultural e geográfico tradicional. Através de um estudo fenomenológico da paisagem e da arquitectura de wancho, revela como estas comunidades criam formas e inscrevem os seus padrões particulares na paisagem, resultando numa expressão única. A fenomenologia enfatiza a experiência vivida e indaga sobre os conceitos relacionados de espaço e lugar, compreendendo como os fenómenos físicos são inscritos com significados. Assim, as povoações de wancho em Arunachal Pradesh foram vistas através da perspectiva da experiência vivida que fornece significados. Nas povoações de wancho, a ligação emocional e subjectiva da comunidade ao seu local é forte, e reflecte-se na realidade material da aldeia e do seu ambiente. Vistas como um todo, as povoações integram factores climáticos e outros factores ambientais naturais, bem como as instituições, valores e práticas culturais destas pessoas, que também se reflectem no artesanato e competências locais da comunidade. As povoações tradicionais de wancho são "lidas" aqui, considerando a sua paisagem e ambiente urbano como "textos".

\section{Introduction}

Phenomenology investigates the world as a lived experience. Phenomenological intuition marks a philosophical and semantic turn in geographical inquiry, where concepts of space and place are used together, highlighting the ways in which these embed themselves in the imagination, including their importance and their structure. Space is layered with use and felt-meaning, and transformed into place. Spaces assume meaning through use and association, and become places. The meanings attached to places are derived as a result of the experiences of people. Such experiences reveal the intimate bonding between the people and the place, evident in cultural practices such as festivities or rituals. Vernacular architecture embodies the notion of the indivisibility of culture and its manifestation through architecture (Parvizi 2009).

Vernacular architecture provides an alternative and critique to modernist approaches that valorize designs lacking local representation (Heath 2009); it embodies continuity, and a collective wisdom of culture (Mouzon 2004). The diverse forms of vernacular architecture highlight the creative work of communities in using the same building material in a variety of different ways, even with a similar topography and climate (Rapoport 1969; Sinha 1989; Glassie 2000). Vernacular architecture expresses the bond between the people and the place in the inherent and reciprocal relationship between the built environment and landscape (Lewis 1979), thus encompassing the buildings, as well as the context, culture, use, symbolism, and varied forms as a collective expression of a community (Bronner 2006;
Oliver 1997; Jackson 1984). Vernacular dwellings embody culture, attaining relatively stable forms of culture that are durable over long periods and are thus "appropriate" (Walkey 1993; Glassie 2000). "Appropriate-ness” informs our understanding of the process of its coming-into-being, incorporating human contexts, which transform meanings that accrue in a "space" into a "place". A phenomenological understanding of vernacular places is thus about experience, entwining the place and culture of a given settlement, such that the essential core and foundation of "human-ness" can be seen more clearly (Harries 1983).

Modernity is accompanied by a rhetoric that conflates the traditional with "backwardness", marginalizing the old or vernacular, and marking an epistemological break with the past. It is presented as the discursive "objective" determination of "facts" and of their universal applicability, leading to an ignorance of the complex social and cultural phenomena of place, including its bonds. This paper investigates "historically relevant cultural values" in landscape (Rogers 2001), through their clear expression in the traditional Wancho village settlements, and addresses the lacuna in the knowledge of how Wancho sites become places through patterns of use and stable meanings inscribed over relatively long periods of time, within the context of community life. In this it corresponds to Foucault's notion of place as a representation of cultural values, norms and ideals. 


\section{The Phenomenology of Vernacular Architecture}

Phenomenology as an interpretive study of human experience aims to examine and clarify human situations, events, meanings, and experiences "as they spontaneously occur in the course of daily life" (Von Eckartsberg 1998: 3). It uses sense-awareness and body-awareness as its means and methods, as these congeal into perception and develop an understanding of the relationship between object and subject in a given space and at a given time. It allows us to investigate the traditional village and its social construct through their spatial organisation, including its dwellings and the exterior spaces, as vernacular architecture has an in-built ingenuity in the way it relates to the environmental, cultural, technological and historical context (Ganguly 2015).

The Phenomenological lens reveals the bond that develops between people and places, as reflected in spatial manifestations and cultural practices such as festivities or rituals. Heidegger understands place as an intimate intertwining of experience and geography. The substance of phenomenological inquiry is the ways and the forms in which this takes place, revealing the geographies of experience and consciousness of the lived world, and the components of the place that make it distinctive (Sancar 1994). The nature of the vernacular in India, as well as the inadequacy of conventional approaches in capturing its essence, demands the "radical empiricism" offered by a phenomenological approach (Tuan 1977; Norberg-Schulz 1979; and others). Vernacular architecture evolves from iterative acts of doing and making. Its method of design is facilitated by a highly structured socio-cultural order that dictates its architectural grammar (Hubka 1986). It is the lack of adequate literature on the architectural ingenuity of vernacular architecture and the strong reciprocal relationship between the built and the un-built that make this kind of study necessary.

Figure 1. The Wanchos in their customary dress (Nokkai Longding Arunachal Pradesh)

\section{Methodology}

This study enquires into the essences of place-meaning through embodied awareness, supplemented by detailed note-taking and reflection, and with participant observation and careful documentation of the settlement. It employs two principal methods to gather primary data: first, an immersive study of the village, by the first author, using careful observation gleaned from sensory, and cognitive sense-making at the Wancho settlement(s), which took place during a week-long stay at Senua in September 2018; and second, understanding developed through unstructured interviews of inhabitants, and matching with observations. It then compares the outcome with other first-person phenomenological studies and information obtained through participant interviews and secondary sources.

Vernacular architecture expresses the human values of the given society, its activities and artefacts, including built form, giving meaning and direction to the lives that occupy it (Oliver 2006). It relies on the economies of material and labor, constituting these into sustainable relationships, and thus invokes the natural environment (Heidegger 1971). This study therefore considers three sources with regard to phenomenology: the character of the natural environment (geology, climate and ecology); the built environment, which is seen as facilitating communication; and finally, the people and their social activities as the foundation of a cultural identity (Violich 1985).

\section{The Wancho}

The Wancho are an important autochthonous tribe inhabiting the Nocte-Thangsa cultural zone, in Tirap and Longding districts of Arunachal Pradesh, India. They are known for their rich traditional knowledge and as warmhearted people and are reputed to be "Head Hunters" and a "martial community". They wear colorful attire and carry guns and spears both as their weapons and as personal ceremonial articles (Fig. 1).The Wancho are scattered over

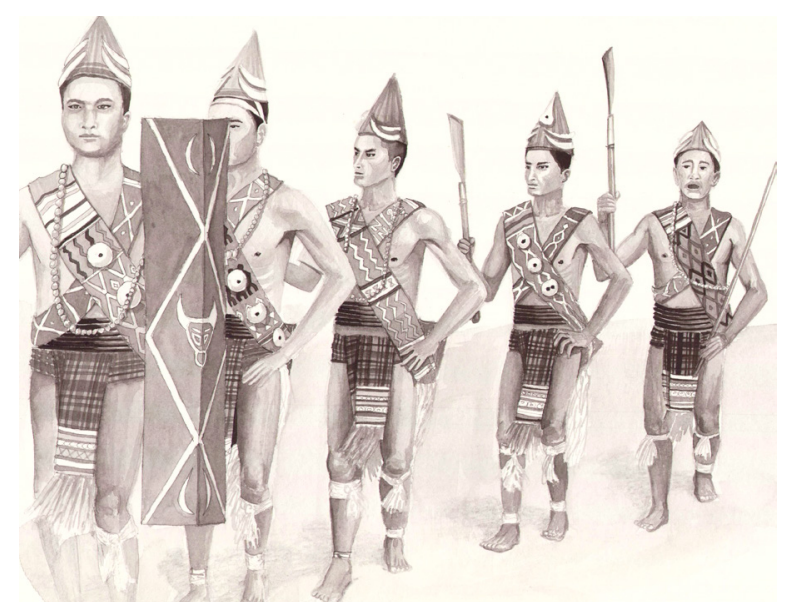




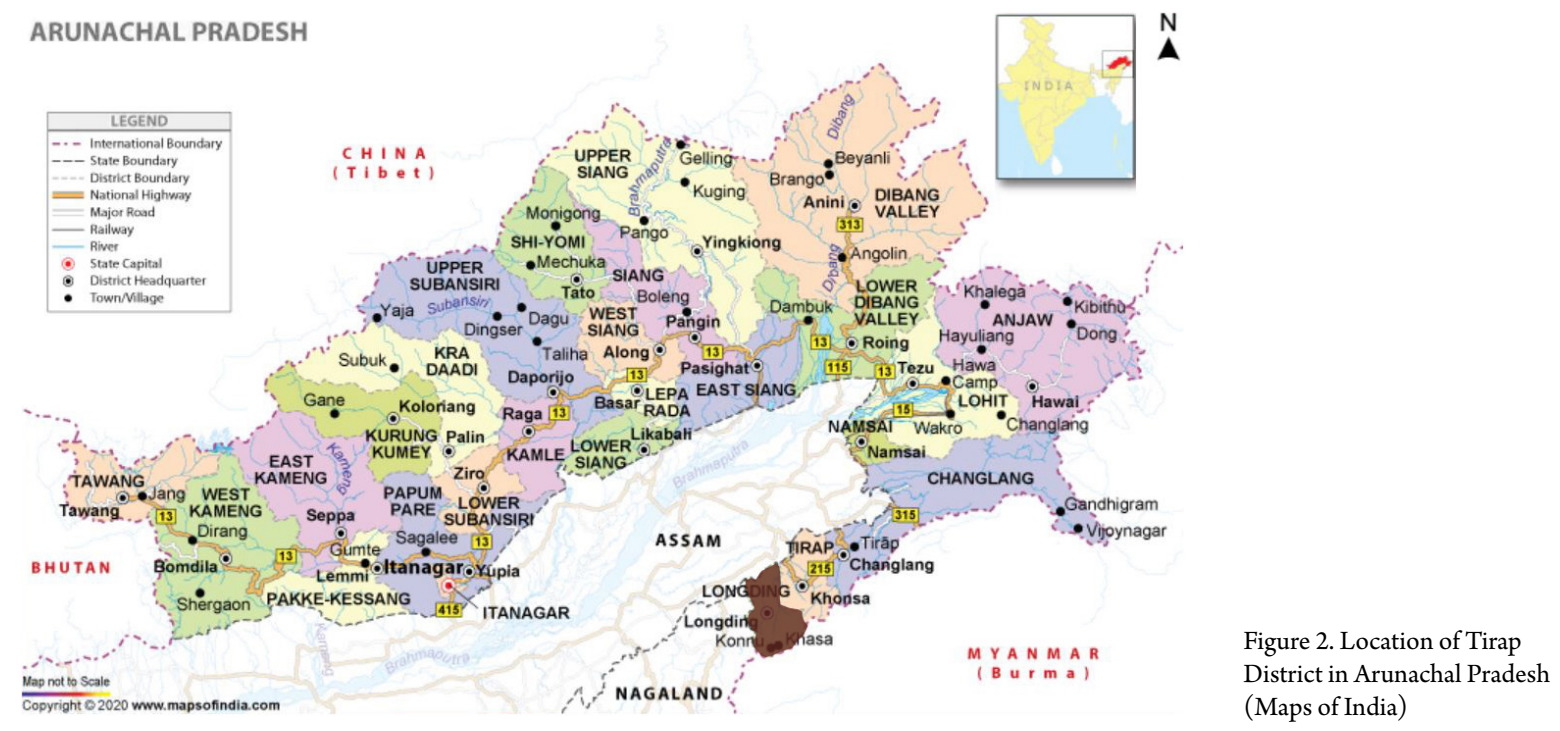

36 villages and divided into 11 Jans. Rulership is hereditary and is reflected in the settlement and dwelling units.

The Wancho have an acute sense of their environment and its resources, and inhabit the peaks and uplands of Longding, with clear views of the surrounding territory. The higher location is strategic, and the fertile slopes are used for farming. The settlement is built in a forest-clearing and divided into four sectors. First, the land is cleared for building houses and community activities; secondly, the land is cleared for the agricultural land within which individual ownership may be allowed; in addition, forest land is earmarked for sustenance; and finally, some land is reserved for future needs. Indigenous laws have been able to protect the biodiversity of the region, and the clan forest management system is still prevalent. Farming, hunting and animal rearing are occupations carried out by every family. Due to the limitation of available land, efficient and well-managed land-use institutions have developed, characterised by sustainable and balanced harvesting.
The Wancho are agrarian and have a rich traditional ecological knowledge. As mentioned, the village settlement (Jan) along with the adjoining land has six different uses: Zim, Chawat, Kap, Jhum, Tham and finally the settlement area, where they build their houses. Zim is the agricultural land for paddy cultivation. Chawat are the traditional vegetable gardens within the homes. Kap are the kitchen gardens in the Jhum fields, the plantation area for bamboo and palm leaves. And Tham are the clan jungles. Farming sectors swap their functions every ten years, so that the farms shift to different sectors, leaving the previous ones to regain their fertility for the next ten years. This practice allows the soil to be protected, restoring nutrients, fallowing and resting of the soil, thereby providing sustainability and a better livelihood (Kerkoff and Sharma 2006; Tanggiang 2009; Tonglong et al. 2014).

Senua Village (Fig. 3) is located six kilometres from Longding on the hilltop. Senua Noksha, another settlement, is situated at the foothills, along the river, and is about seventeen kilometres from Longding.

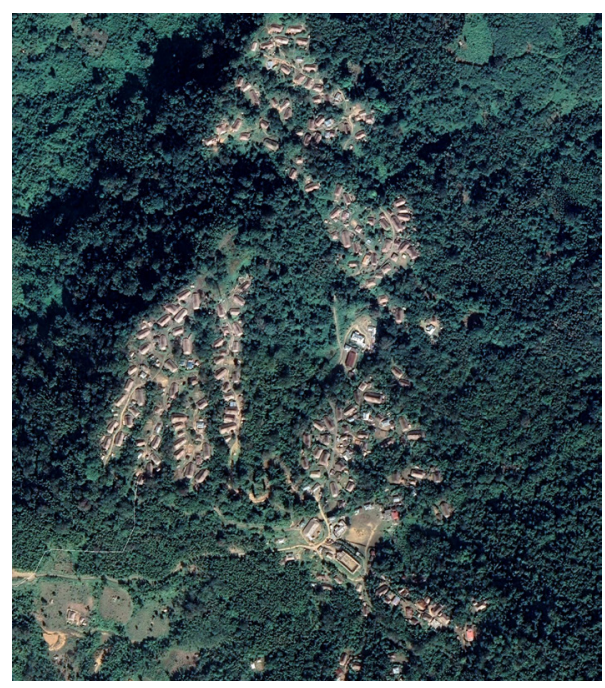

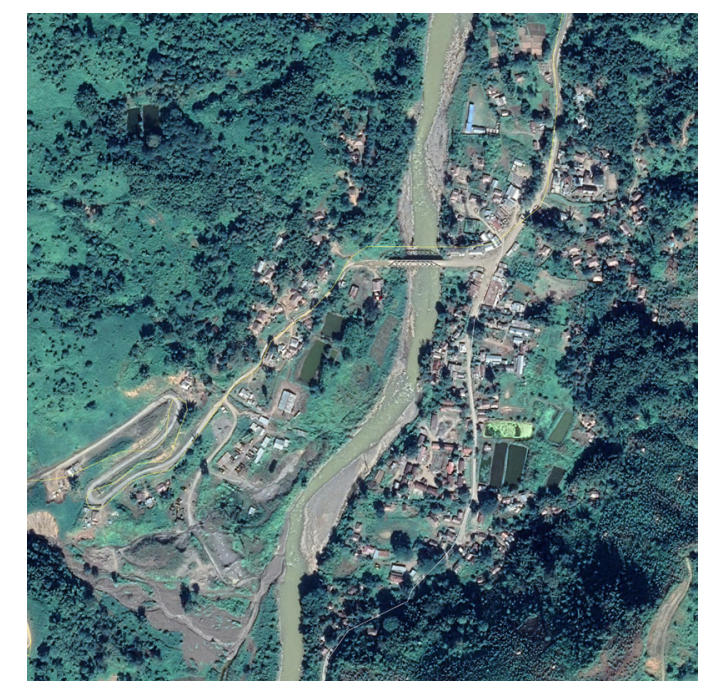

Figure 3. Satellite images of Senua Village and Senua Noksa (Google Maps, 2018) 

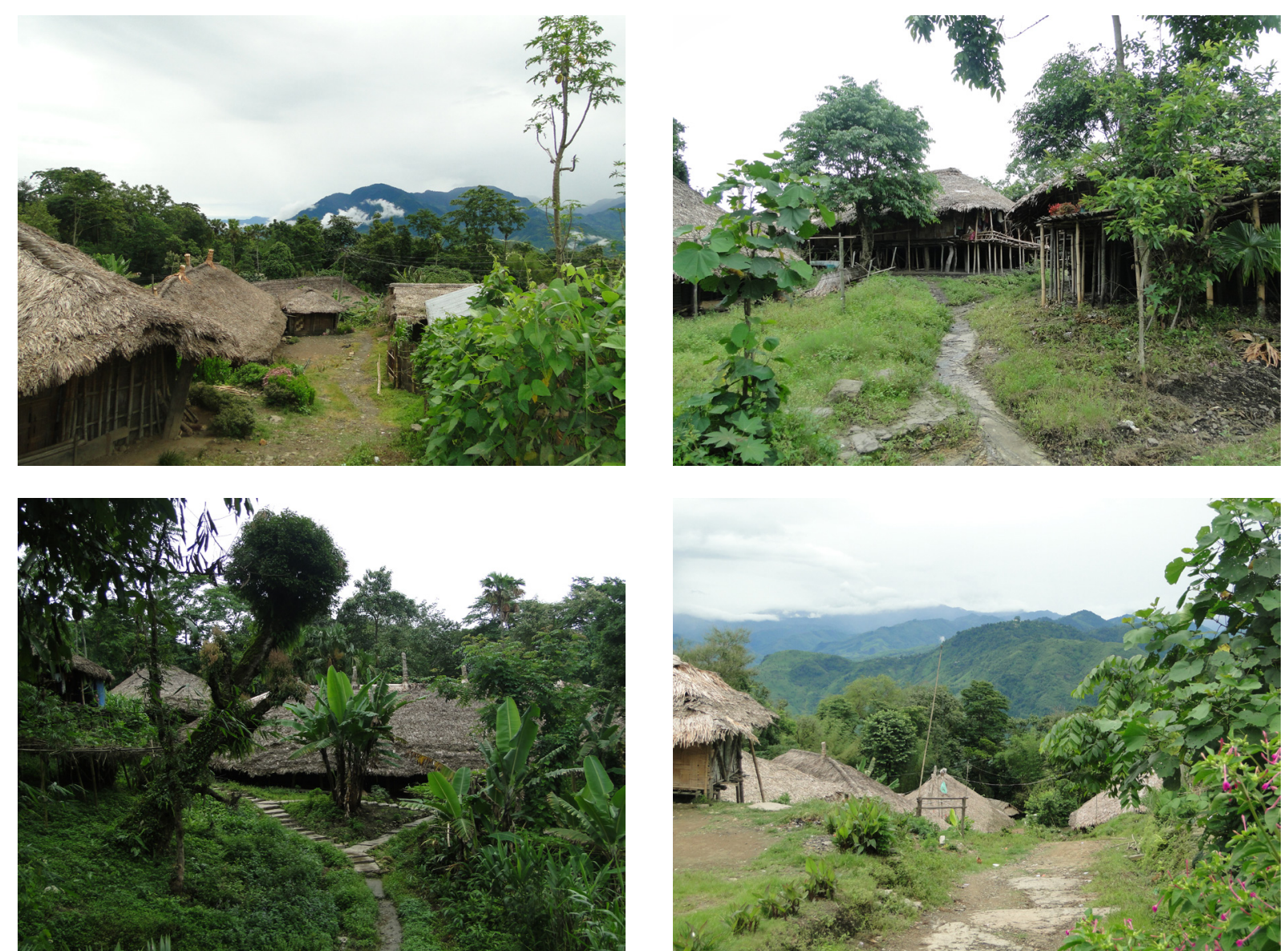

Figure 4. Retaining walls that are either made of stone or bamboo suggest a strong connection with the surrounding landscape

\section{Natural Environment as an underlying determinant of spatial and social structure}

The natural environment of the Wancho forms the basis for the character of the place and the pattern of their life in it, integrating the landscape relationship which sustains and preserves it. The communities select comparatively gradual slopes to settle down and construct their dwelling units (Fig. 3). The street pattern (along the slope) and the building footprint (across the slopes) are dictated by the natural terrain, vegetation, and the visual connectivity of the surroundings. The dwelling units are lived in for generations and are placed along the street and across the contours in a seemingly-random, but highly intuitive manner, carefully utilizing available land. A portion of each house is built from the ground up, while some of it is built on stilts, resulting in minimal retaining walls (Fig. 4).

The spatial structure of the settlement and the dwelling units in Senua, for instance, is tightly-knit and "organic" - growing from/into, and deepening the mountain atmosphere. Indigenous laws followed by the community in Senua protect the biodiversity of the region, and the traditional forest management system of the clan is prevalent within the village community. The sustainable harvesting of bio resources is also apparent in the traditional system of forest management, bamboo plantation, and the use of land and water resources. "Nature" is embodied through in-dwelling with environment/ecology. The settlement pattern and the methods and practices associated with their livelihood establish the character of the natural environment that is intrinsic to the Wancho.

The built and socio-cultural environment as cultural identity

The Wancho society is divided into two distinct social divisions: Wangham (the chiefs) and Wangpan (the common class). Apart from this, there are two intermediate classes: children with a Wangham father and Wangpan mother are called Wangsa, and children with a Wangsa father and Wangpan mother are called Wangsus.

The chief of the village generally marries the daughter of the chief (Wangsia) of another village and the children born from them will be Wangham and Wangsia too. But both monogamy and polygamy are practiced, and the Wangham can have more than one wife. Though there are two major social distinctions in the tribe, as mentioned above, marriages between the two are permitted, which forms the two intermediate classes within the tribe. 
The village council (Ngo Thun) or Genpo consists of the Wangham, the chief; his assistant and announcer, called the Ngwapa; and the Nangchu-Wangeha, the Council of Elders. Recent councils have also started including the Gaon Bura (village head) or the Government Nominee. This body is primarily responsible for the smooth administration of the villages and for implementing the customary laws for the holistic management, conservation and sustainable use of forest diversity wealth.

Post-marital residence is patrilocal. The father is head of the family and the eldest son inherits the paternal property and the mantle of the family head after his death.

Apart from the main classes, the Wancho village has several clans. Each village is divided into Jong. Each Jong has its own common dormitory for boys or morung, called $\mathrm{Pa}$ (Fig. 4). The clan comes together in times of need, under the institution of the village chief. The members of the $\mathrm{Pa}$ maintain order and peace in the society in matters where the chief's intervention is not deemed necessary. The hierarchical system is understood by all, who must obey its code. At least two $\mathrm{Pa}$ are present in every village and its number increases according to the settlement size and population. Senua, for instance, has three $\mathrm{Pa}$. The $\mathrm{Pa}$ are both secular and sacred, sheltering deities. They are visited for ceremonies by every male of the tribe, who are first admitted in childhood and continue to visit them until death. They were also once the final resting place for enemies' skulls. Nowadays, since most of the Wanchos have taken up Christianity as their faith, the enemy skulls have been buried. Only the skulls of animals they hunt remain on display in the $P a$. As the members of the family are constantly engaged in farming, hunting, and animal rearing, the institution of $\mathrm{Pa}$ encultures the children of the tribe, teaching them discipline, skills like hunting and self-defense, farming, cooking, weaving, carving and other arts. Admission into a $\mathrm{Pa}$ requires offering this institution spices, crops, meat, and lumber for burning. One has to offer these in considerable quantities, which are specified by the $\mathrm{Pa}$ itself. The house of the clan chief is used as a girls'

Figure 5. $\mathrm{Pa}$ (Morung) is a sacred institution for the Wancho. Skulls of animals hunted by $\mathrm{Pa}$ members are displayed at the entrance of their $\mathrm{Pa}$, where the musical instrument named Kham is also kept

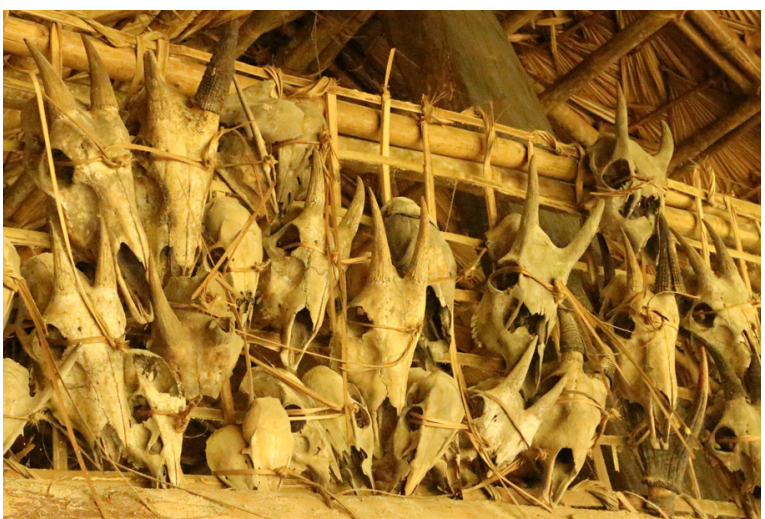

dormitory and they are looked after by the wife of the clan chief. The boys are allowed in this dormitory but the girls are not allowed in the Pa or morung (Singh 1995).

The structure of the $\mathrm{Pa}$ is very similar to that of a regular house. It has its front side open and multiple entrances. The interior is divided into two parts, one with a bamboo matted floor (Wado) and the other directly on earth. The Wado area is used for meetings and meals and is equipped with a fireplace that also acts as a stove for cooking. The rear part is used for sleeping.

The $\mathrm{Pa}$ also has a huge musical instrument (Kham) for announcing emergencies or important events when needed. It is considered one of the largest musical instruments in the world and is played by multiple people at the same time. It is made of a hollow wooden cylinder which is played by striking it with wooden pegs.

The Ozele Festival in February marks the beginning of the sowing season. It is a small prayer gathering around the chief's house, where the entire village feasts and enjoys itself around the fire. Male members of the community gather at the sacred place, and participate in martial sports like archery, shooting, etc. At the end of these events, the chief announces the sowing season, and the spirits are propitiated with liquor and meat. The Oriya Festival is a larger celebration which can last even longer than a
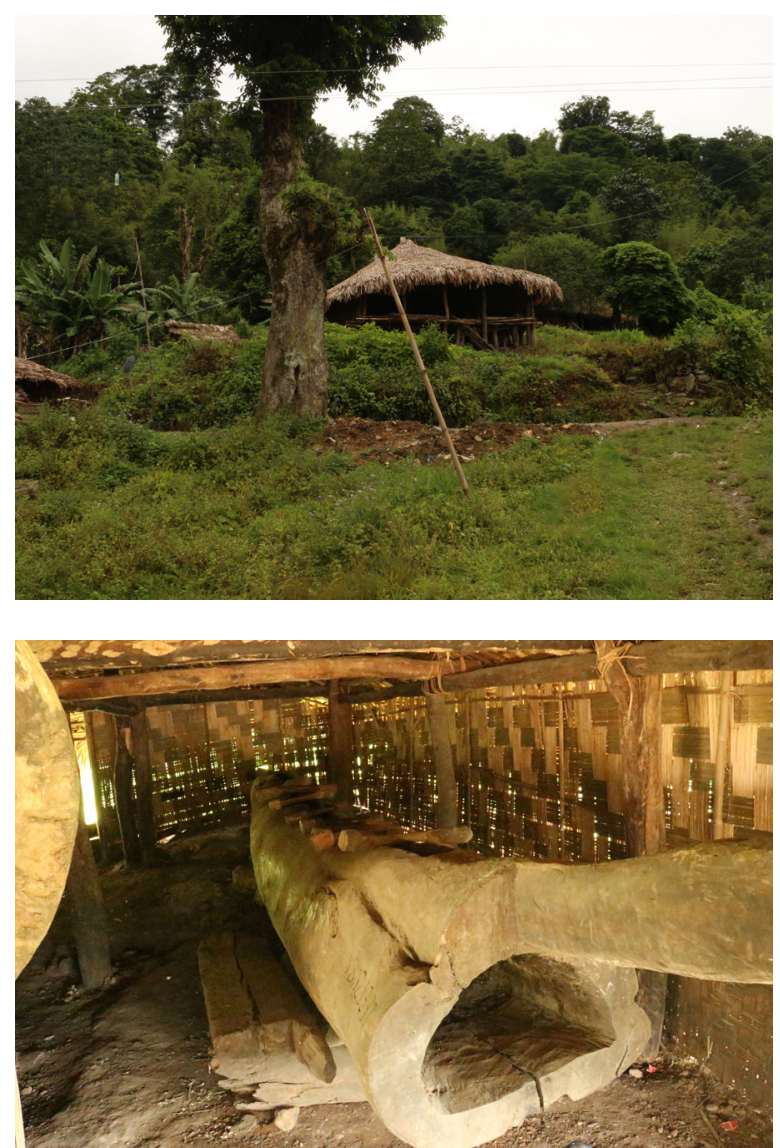
week and marks the harvest season. The Wancho pray to the natural forces, and the gifts of nature are honored. Temporary structures which are later dismantled are used for this event. Apart from these two key festivals, smaller celebrations, ranging from six to sixteen a year, are celebrated yearly in all villages; Panjum, Pangrum, Sachavan and Chkasai are a few examples. The Ozele and the Oriya festivals were also previously local events, celebrated in each village, but are now celebrated among the larger Wancho community. Celebration, ceremonies and rituals such as animal sacrifices are markers of time, have distinct functions, and are an intrinsic part of the cultural identity of the tribe, as are also the diverse dancing forms of boys and girls. The space of these festivities, ceremonies and rituals is part of the spatial order of the village or the community and is renewed for each cycle, renewing identity through ceremony.

The motifs of the Wanchos' customary tattoos are taken from nature and play a major role in local traditions. These tattoos are modes of expression that reveal the status of each person and are a symbol of the identity of this community, though the influence of Christianity seems to be leading to their decline. Men mark their limbs and face to signify success on their head-hunt and warriors use them to display their reputation, while women use decorative designs to signify their coming-of-age and other phases of life. Neck tattoos on women signify if they are engaged or married.

The built environment reflects all these social structures and cultural practices. The location and size of a dwelling unit in the Wancho village reflects the position of its inhabitant within the hierarchy. The Wangham (chiefs) occupy the highest point in the topography and the Wangsa and then Wangsu are next, while the dwellings of the Wangpan (common people) are located at the lower points of the slopes. This spatial hierarchy in the settlement pattern creates a spatial logic that reflects the social order of the community.

Each village also contains markers for dividing the sacred from the profane, constituting separate realms. The sacred is widespread in the Wancho environment. For instance, Wanchos believe that places that have been struck by lightning host evil spirits. A stone at the river-bank may mark a ceremonial place to propitiate Sholom Shom, the river god. At the entrance to a village, ritual structures called Paan-kha are constructed to prevent the access of evil forces. In death rituals, the body of the deceased is kept on a bamboo platform (rookh) with his or her personal

Figure 6. Pattern of bamboo matting on the walls and skulls of hunted animals display in and outside the house
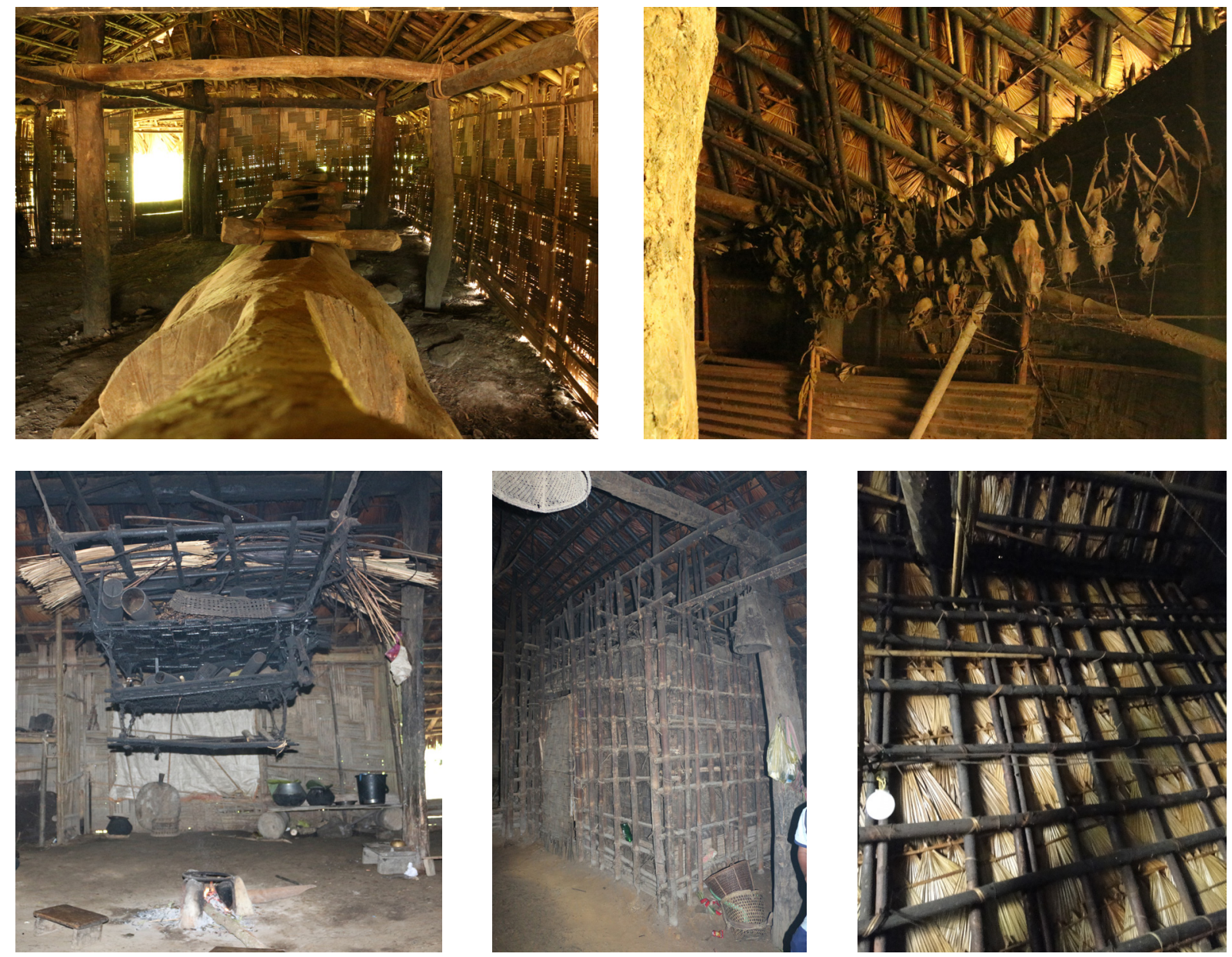
belongings. The body is not buried but the skull is buried. After 15-20 days the family goes to the rookh and cleans the skull, places it in a clay pot and then takes it to the burial ground. When the chief dies, the rookh is constructed near his house, but this is not the case for Wangpans. All these tangible elements, with their own architecture, also contribute to the cultural identity of each village.

At the same time, the houses are also a sacred place for the Wancho, and specific rituals take place in them. The naming ceremony (Katjo), for instance, is performed by the oldest man within the family house. At the age of two or three the little boy has to walk three times round the house with a small basket with light items hung over his back. At the age of 12-15 another ritual is performed which enables the boy to become a member of the morung or $\mathrm{Pa}$ (boys' dormitory), and from then on he starts wearing the langoti (loincloth) (Fig. 6).

\section{Wancho house as identity}

The Wancho house is constructed using wooden logs as posts, bamboo framework, bamboo mats for walls and floors and thatched roofs made of Toko leaves (Fig. 10). The size of the house depends on the size of the family. Friends and relatives of the family provide help in the construction of the house. All the houses are mostly similar, with minor modifications driven by the nature of the site, the social position of the owner or the needs of the family. If the house is very large, they may choose to build it as close to the forest as possible, as carrying large logs over long distances is complicated. As mentioned above, the location of the house within the settlement also depends on the position of the family within the society.

However, the Wancho house symbolises its owner's place in Wancho society not just through its location within the settlement, but also through its building materials and their patterns. The chief's house usually has wood carvings depicting tigers, the royal animal. The walls of the houses display heads of hunted wild animals like bulls or wild boars as a sign of the courage of its owner (Fig. 6). The houses of the chiefs and the council members are built with an inclined bamboo pattern made of full solid bamboo (Fig. 6 ). The houses of the common people show a vertical and horizontal pattern made with full split bamboo (Fig. 6). Within the house, there might be several rooms for the various couples in the family. To differentiate the room of the head of the family from those of the others, an additional crisscross layer of full bamboo caging is added (Fig. 6).

Regarding its form, a typical Wancho house has a rectilinear plan and is curved at one end (Fig. 8). This end has the largest entrance to the house and is always oriented uphill, so it is the part of the house which stands directly on the ground. The central columns (Phak) in the house are also named according to their location and significance (Fig. 8). The column towards the back of the house, the closest to the balcony, is called the Wading Thongnu. The one at the junction between the common space and the sacred space is called the Wado Thongnu - as it is located at the beginning of the matted floor (Wado) (Fig. 8). The column within the sacred area is called Sakoh Thongnu, meaning "sacred pillar", and it is the first column of the house to be erected after a ritual is performed. Before beginning the construction of a new house, a buffalo is sacrificed and then offered to all the people involved in the building process. The sacred area of the house is where rituals and ceremonies are performed. Due to the conversion of the community to Christianity, the sacred pillar now commonly has a cross and a picture of Jesus hung on it. The central pillars are the highest and extend above the roof (Fig. 8). This extra length of the pillar is kept un-cut, so that the moist base in contact with ground can be cut periodically and the same post can be used for a longer time. The platform of the house (Wado) extends beyond the back wall and forms a space like a verandah.

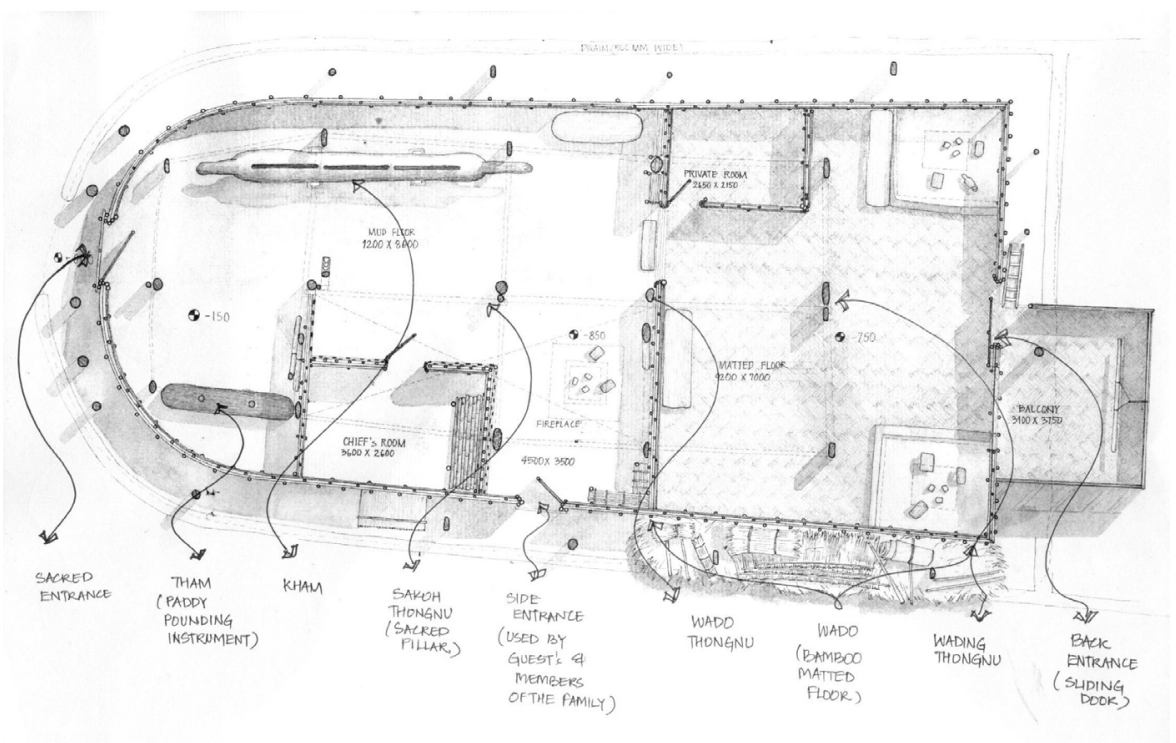

Figure 7. Typical plan, front and side elevation of a Wancho house (Vernacular Studio, School of Planning and Architecture, Bhopal) 

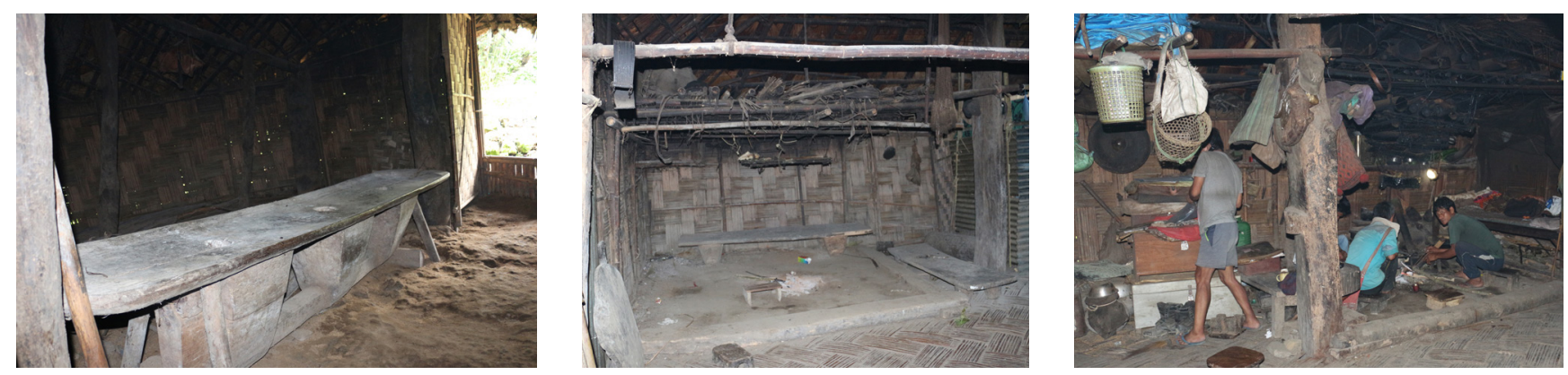

Figure 8. Tham rice pounding tool and fire place. The smoke of the latter disinfects the interior of the house and forms a soot layer over the bamboo in a way that protects the bamboo from insects and corrosion

This space is used for storing dried leaves, bamboo posts, small pig-houses, utensils and other household material, as well as for sunbathing and drying clothes, utensils, etc. The house also has a mezzanine floor under this area that is used to store baskets and other items.

When entering the house from the front, one steps into an area where harvested rice is ground with a locally made instrument called the Tham (Fig. 8). In the chief's house, this area has a different instrument called the Kham (Fig. 5). As this instrument is not found in the houses of other people (Wangsa, Wangsu or Wanpan), the Kham also symbolises the identity of the dwelling. This first area of the house has an uneven mud flooring. Just next to this first area is the sacred space, which is therefore the central part or the core of the house. This sacred space contains the bedroom of the head of the family and is used for functions like dining, cooking, and all the rituals of the family; it has a separate entrance from the outside which is used for welcoming guests (Fig. 8), and it extends as far as the bamboo matted floor (Wado). This matted floor is a gathering space and also contains the bedrooms for the rest of the couples in the family. The number of rooms in this part of the house depends on the number of couples in the family (Fig. 8). This gathering area also has fireplaces for keeping the place warm, as well as for cooking in case of a large gathering, but their most common function is to host the male members of the family while they chat and drink their locally made brews.

Sunlight plays an important disinfecting role, but as there are no windows in the house this sunlight function is replaced by the fumes of the fires lit inside the house. Fumes form a layer of black soot over the bamboo which protects and increases the durability of the bamboo and keeps insects away (Fig. 9).

\section{Conclusion}

Various approaches to vernacular architecture continue to be debated (Belz 2012; Vellinga 2004; Heath 2009; Mouzon 2004; Oliver 2006), converging on the need for mindful change and research that focuses on social aspects and shows a respect for hybrid vernacular landscapes. Vernacular traditions are adaptable, so mindful change is possible and vernacular architecture can still be the way to build for the $21^{\text {st }}$ century (Rudofsky 1964; Jackson 1976; Jordan and Kaups 1987; Blake and Smith 2000; Heath 2001; Heath 2009; Bronner 2006; Belz 2012). This can also be true for the Wanchos from Arunachal Pradesh.
Figure 9a. Major spaces in the Wancho house, construction method and materials used to build the house (Vernacular Studio, School of Planning and Architecture, Bhopal)

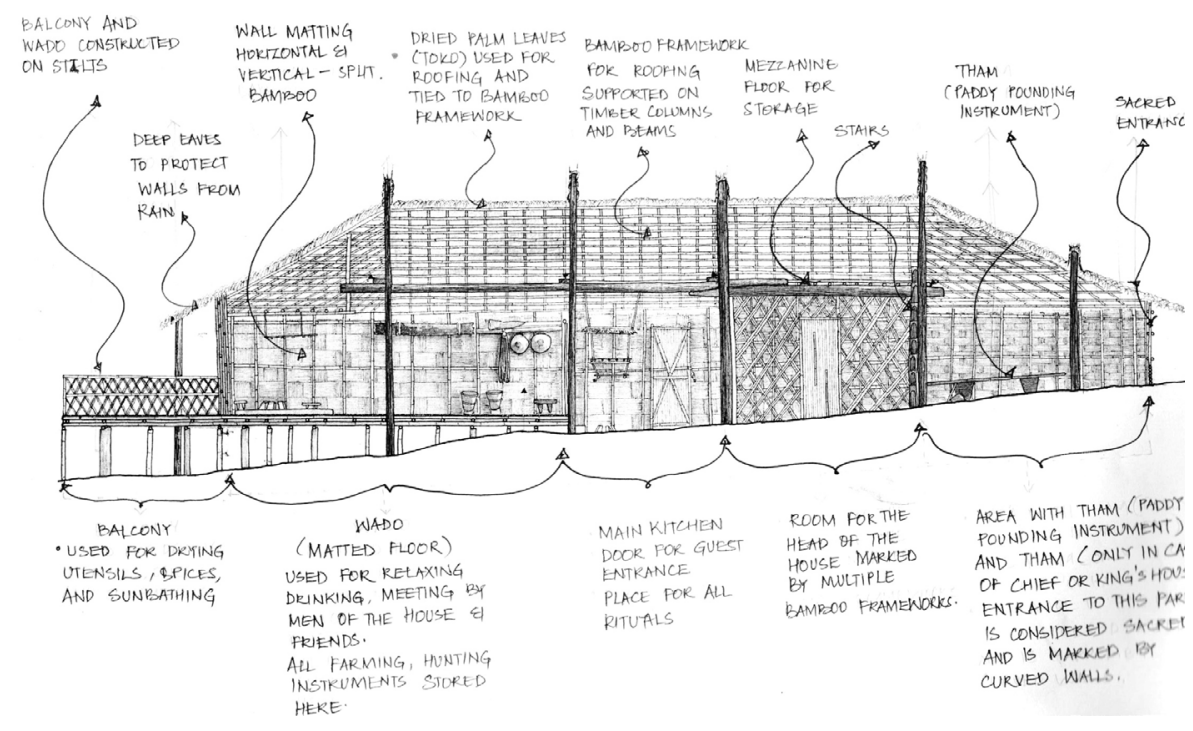




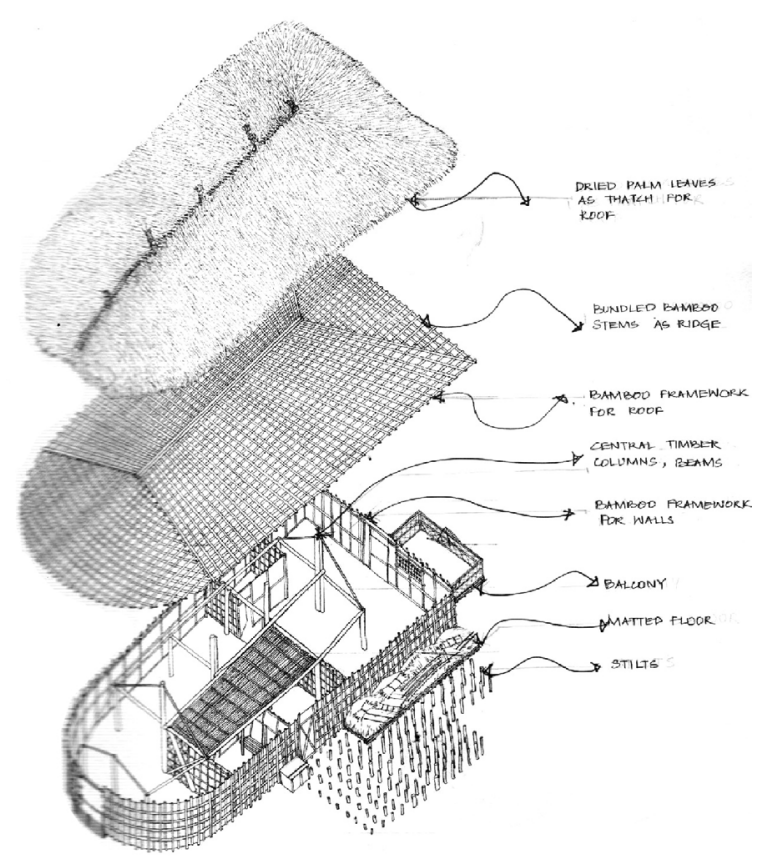

Figure 9b. Major spaces in the Wancho house, construction method and materials used to build the house (Vernacular Studio, School of Planning and Architecture, Bhopal)

The world is constituted as an image formed by the mind's perception of spaces, including natural elements, architecture, and people. This perception of the inhabited world, if it is successfully grasped in architectural works, may lead to increasing levels of satisfaction (Duc Minh Tran 2017). Vernacular Architecture provides stable images for them. Its inhabited spaces are mediated by individual and community perceptions, expressing the indigenous adaptation to climate and topography (Rudofsky 1964). The Vernacular expresses and fosters attachments to place by connecting culture, history, and ecology to geographical identities, producing specific characters and a unique sense of place (Hester 1993; Lewis 1979; Pocius 1991). This is not merely embedded in the physical qualities of a location, but becomes an individually and socially constructed process that transforms a space into a place (Beidler 2007). The reciprocal relationship between the spatial and social structure followed by cultural practices provide the vernacular settlements with three attributes: "identity, structure and meaning" (Lynch 1960), also stimulated by sight, sound, smell or tactile information (Porteous 1996). For these very reasons, the Vernacular becomes an excellent vehicle for place-making.

In the case of the Wancho village, the $\mathrm{Pa}$ (morung) in every jong signifies the social order of the given jong within the village, thus creating a strong particular sense of place. The Wancho settlement reflects the hierarchical positioning of the dwelling units as the spatial manifestations of the social order, providing the socio-spatial orientation. The many spatial types within the Wancho village of Senua coalesce as a single identity and suggest communitarian ownership among the people of the village. Additionally, the Wancho's sense of harmony with their natural environment is reflected in each aspect of their settlement, from the house, in both its disposition and form, to the larger pattern of streets, which appears to have negligible impact on the land. Each settlement is respectful towards the place and exudes an intimate "natural" character.

The Wancho retain significant place attachments which are seen in their settlement as well as in the wider landscape. The cyclic festivals and rituals on special occasions renew place-meanings and the sense of identity, affirming the spatial order. Each aspect, whether tangible or intangible, is bound to the other and sensitive to change.

Although Christianity has brought about recent and noticeable change to their rituals, especially those conducted for the deceased, Wancho tradition has been maintained in other rituals, as in their architecture itself. Ritual and everyday practices of the community maintain their ecological basis. While modern conveniences and appliances are appearing in domestic spaces, the community still follows the traditional system of forest management, bamboo plantation and careful use of land and water resources.

In Wancho culture, building construction is primarily a community exercise of ordering space through its social order, rather than simply occupying a site. The passing on of traditional knowledge covers not only how to build, but what to build. The identity of each space is defined not only by its physical characteristics, but also by its various associations in the form of rituals, memories, ownership, representation and ornamentation.

Although Wanchos only exemplify a singular vernacular settlement, there are parallels in all indigenous villages, where a sense of place is developed through a mixed interpretation of the space and its meanings.

\section{Bibliography $\mid$ Bibliografía | Bibliografia}

Asquith, Lindsay; and Vellinga, Marcel (eds). 2005. Vernacular Architecture in the Twenty-First Century: Theory, Education and Practice. New York: Taylor and Francis.

Beidler, Kyle Joseph. 2007. Sense of Place and New Urbanism: Towards a Holistic Understanding of Place and Form. PhD Thesis from the Virginia Polytechnic Institute and State University, Blacksburg, Virginia.

Belz, Melissa Malouf. 2012. Spirit of Place and the Evolution Of The Vernacular House In Kinnaur, Himachal Pradesh, India. PhD Thesis from the Department of Geography, Kansas State University, Manhattan, Kansas.

Blake, Kevin; and Smith Jeffrey. 2000. Pueblo Mission Churches as Symbols of Permanence and Identity. The Geographical Review, vol. 90, 3: 359-380. 
Bronner, Simon J. 2006. Building tradition: Control and authority in vernacular architecture. In Asquith, Lindsay; and Vellinga, Marcel. Vernacular architecture in the twenty-first century: Theory, education and practice: 23-45. London: Taylor \& Francis.

Duc, Minh Tran. 2017. The Continuing Of Organicism: An Enviro-Organic Form Integrating To The Built Environment. Phd Thesis from the University Of Hawaii At Manoa.

Ganguly, Rupa T. 2015. Role of Vernacular Architecture of India In Green Building Design - A Case Study of Pauni. International Journal on Recent and Innovation Trends in Computing and Communication, vol. 3, 2: 130-135.

Glassie, Henry H. 2000. Vernacular Architecture. Bloomington: Indiana University Press.

GOI. 2011. Census of India 2011: Provisional Population Totals. New Delhi: Registrar General and Census Commissioner of India, Ministry of Home Affairs.

Heath, Kingston Wm. 2009. Vernacular Architecture and Regional Design: Cultural Process and Environmental Response. London: Architectura Press.

Heath, Kingston Wm. 2001. The Patina of Place: The Cultural Weathering of a New England Industrial Landscape. Knoxville: University of Tennessee Press.

Hester, Randolph. 1993. Sacred Structures and Everyday Life: A Return to Manteo, North Carolina. In Seamon, David; and Mugerauer, Robert (eds.). Dwelling, Place and Environment; Towards a Phenomenology of Person and World: 271-298. Malabar, Florida: Krieger Publishing Company.

Hubka, Thomas. 1986. Just Folks Designing: Vernacular Designers and the Generation of Form, In Upton, Dell; and Vlach, John Michael (eds.). Common Places: Readings in American Vernacular: 426-432. Athens: University of Georgia Press.

Hughes, Vincent. 2002. Engendering a Sense of Place: Why are Some Places More Successful than Others? Landscape Design, 308: 33-36.

Jackson, John B. 1984. Discovering the Vernacular Landscape. New Haven: Yale University Press.

Jackson, John B. 1976. Domestication of the Garage Landscape. Places Journal, 20, 2: 10-19.

Jordan, Terry; and Kaups, Matti. 1987. Folk Architecture in Cultural and Ecological Context. Geographical Review, 77, 1: 52-75.

Kerkoff, Elisabeth; and Eklabya, Sharma. 2006. Debating shifting cultivation in the Eastern Himalayas: Farmer's innovations as lesson for policy. Kathmandu: International Centre for Integrated Mountain Development (ICIMOD).

Knack, Ruth; and Bunnell, Gene. 2003. A Suburban Success [and] How the City Center Marketplace Helped to Strengthen Westminster's Identity and Sense of Place. Planning, 69, 1: 30-33.

Lee, Thomas. 2000. Place Making in Suburbia: Reinventing Suburban Communities with a Sense of Place. Urban Land, 59, 10: 72-79 and 112-113.

Lewis, Peirce F. 1979. Defining a Sense of Place. The Southern Quarterly, 17(3\&4): 24-46. The University of Southern Mississippi.

Lynch, Kevin. 1960. Image of the City. Cambridge, Massachusetts: MIT Press.

McMurry, Sally; and Annmarie, Adams. 2000. People, Power and Places: Perspective in Vernacular Architecture. Knoxville: University of Tennessee Press.

Mouzon, Stephen A. 2004. Traditional Building Patterns, New York: McGraw Hill.

Norberg-Schulz, Christian. 1979. Genius Loci: Towards a Phenomenology of Architecture. New York: Rizzoli.
Oliver, Paul, 2006. Built to Meet Needs: Cultural Issues in Vernacular Architecture. Oxford: Elsevier.

Oliver, Paul, 2003. Dwellings: The Vernacular House World Wide. London: Phaidon Press

Oliver, Paul 2007. Encyclopedia of Vernacular Architecture of the World. Abingdon: Routledge.

Pocius, Gerald L. 1991. A Place to Belong: Community Order and Everyday Space in Calvert, Newfoundland. Athens, Georgia: The University of Georgia Press.

Porteous, John Douglas. 1996. Environmental Aesthetics: Ideas, Politics and Planning. London: Routledge.

Rapoport, Amos. 1982. The Meaning of the Built Environment, a Nonverbal Communications Approach. Tucson: University of Arizona Press.

Rapoport, Amos. 1969. House Form and Culture. Englewood Cliffs, New Jersey: Prentice-Hall.

Rudofsky, Bernard. 1964. Architecture Without Architects: An Introduction to Non Pedigreed Architecture. Albuquerque: University of New Mexico Press

Salvesen, David. 2002. The Making of Place. Urban Land, 61, 7: 36 - 41.

Sancar, Fahriye Hazer. 1994. Paradigms of Postmodernity and Implications for Planning and Design Review Processes. Environment and Behavior, vol. 26, 3: 312-337.

Singh, Kumar Suresh.1995. Arunachal Pradesh. In Singh, Kumar Suresh; Parul, Dutta; and Ahmed Syed, Ishteaque (eds.). People of India, Anthropological Survey of India. Calcutta, India: Seagull Books.

Sinha, Amita. 1989. The Traditional Rural Settlements and Dwellings in Northern India, Traditional Dwellings and Settlements. Working Paper Series, vol. 6: 117-140.

Ozkan, Suha. 2006. Traditionalism and Vernacular Architecture in the Twenty First Century. In Asquith, Lindsay; and Vellinga, Marcel. Vernacular architecture in the twenty-first century: Theory, education and practice: 23-45 London: Taylor \& Francis.

Tangiang, Sumpam. 2009. Traditional Slash and Burn Agriculture as a holistic land use Practice: A case from the ethnic Noctes in Arunachal Pradesh. Calcutta: World Journal of Agricultural Sciences.

Wangpan, Tonglong; Taka, Tapi; Tangjang, Sumpam; and Arunachalam, Ayyanadar. 2015. Sustainability of Indigenous Farming Practices: A Case Study among Apatani, Nocte and Wancho tribes in Arunachal Pradesh, Northeast India. International Journal on Agricultural Sciences, vol. $6,1: 103-108$

Tuan, Yi-Fu. 1977. Space and Place: The Perspective of Experience. Minneapolis: University of Minnesota Press.

Vellinga, Marcel. 2004. Constituting Unity and Difference: Vernacular Architecture in a Minangkabau Village. Leiden: KITLV Leiden.

Violich, Francis. 1985. Towards Revealing the Sense of Place: An Intuitive "Reading" of Four Dalmatian Towns. In Seamon, David; and Mugerauer, Robert (eds.). Dwelling, Place and Environment; Towards a Phenomenology of Person and World: 113 -136. Leiden: Martinus Nijhoff Publishers.

Walkey, Ron. 1993. A lesson in Continuity: "The Legacy of the Builders" Guild in Northern Greece. In Seamon, David (ed.). Dwelling Seeing and Designing: Toward a Phenomenological Ecology: 129-157. Albany: State University of New York Press. 
Biographies | Biografías | Biografias

\section{Sanjeev Singh}

$\mathrm{He}$ is a Professor in the Department of Architecture of the School of Planning and Architecture (SPA) of Bhopal and an Architecture graduate from the Government College of Architecture (now Faculty of Architecture of the Abdul Kalam Technical University, Uttar Pradesh). He holds a Master in Environmental Studies from Melbourne University and a $\mathrm{PhD}$ from the National University of Singapore. His research interests are in the fields of Vernacular Architecture, Cultural Landscapes and environmental studies. He has been conducting the Vernacular Studio at SPA Bhopal for the past nine years and his publications refer to his interest areas. Presently he is also holding the position of Dean of Planning and Development at SPA Bhopal.

\section{Saurabh Popli}

He teaches Architecture and Landscape Design at the School of Planning and Architecture, Bhopal. He is interested in the contemporary imagination and representation of ideas in Architecture and the Landscape. He has an enduring interest in the connections between art and design, and in the ways in which architectural and landscape-thinking blurs disciplinary and sectoral boundaries. His research has focused on complex, contested, and obscure ways in which landscape shapes culture, and is shaped by people. His teaching, research and writing pertains to themes of sustainability, urbanism, design, aesthetics, resource-use, as well as societal transitions towards resilience through stakeholder negotiation and mutuality. Saurabh has given classes on Indian landscapes at well-known Indian universities and has participated in national and international design studios and conferences. 